\title{
Role of nutrients regulation in the immune system in preventing COVID-19 infection: A brief review
}

\author{
Anamika Chauhan \\ Department of Home Science, Chamanlal Mahavidyalaya, Landhaura, Roorkee, Haridwar \\ (Uttarakhand), India \\ Email: anamikachauhan1615@gmail.com
}

\section{Article Info}

https://doi.org/10.31018/

jans.v13i2.2572

Received: February 17, 2021

Revised: June 5, 2021

Accepted: June 9, 2021

\section{How to Cite}

Chauhan, A. (2021). Role of nutrients regulation in the immune system in preventing COVID-19 infection: A brief review. Journal of Applied and Natural Science, 13(2), 760 - 765. https://doi.org/10.31018/jans.v13i2.2572

\begin{abstract}
This review aimed to focus on using foods to boost immunity against COVID-19 in all age groups. In human, coronavirus causes the common cold, severe acute respiratory syndrome (SARS), and a major threat to public health. The novel coronavirus was declared a pandemic by the World Health Organization due to its rapid infectivity. COVID-19 infection is most probably reported in people with low immunity response. The nutrients, which show beneficial effects on the immune system, are called immune nutrients and diet is called immune diet. A healthy diet can reduce the risk of infection of COVID-19 and can prevent disease. Nutritional food intake is also necessary for people with chronic illness, obese persons, diabetes, cardiovascular disease, cognitive dysfunction like anxiety and depression. All nutrients are essential for maintaining immunity and providing appropriate amounts of protein, fat, carbohydrate, vitamins, and minerals for the surveillance mode of keeping us from getting sick. The use of plenty of water, minerals such as micronutrients, zinc, copper, selenium, iron, magnesium, food rich in vitamins, and a good lifestyle can promote health and overwhelm this coronavirus infection.
\end{abstract}

Keywords: COVID-19, Immunity, Nutrients, Regulation

\section{INTRODUCTION}

A pneumonia outbreak occurred in Wuhan, Hubei Province of China, in December 2019, affecting people's health globally. On December 31, the Municipal Health Committee of Wuhan informed the World Health Organization (WHO) that 27 people were diagnosed with pneumonia, of which 7 persons were seriously ill (International Society for Infectious Diseases, 2020). In the month of January 2020, the first cases of COVID-19 were reported outside China, with 02 cases in Thailand and 01 in Japan. Due to the rapid spread of the disease, the WHO declared it as a health emergency of international concern. COVID-19 was detected in all the provinces of mainland China and also diagnosed in 15 other countries. By March 2020, it was reported in more than 100 regions worldwide and was recognized by the WHO as a pandemic.

In India first case of COVID-19 infection was reported in Kerala. A 20 years old female presented to the Emergency Department in General Hospital, Thrissur, Kerala, on January 27,2020 , with the problem of dry cough and sore throat.

The COVID-19 is caused by a RNA virus, which causes severe acute respiratory syndrome coronavirus2 (SARS-CoV-2) and affects the respiratory system. The spread of droplets can transmit this virus to an infected person. It can be an asymptomatic disease or present mild infection of the upper respiratory tract. Most severe cases are characterized by acute respiratory distress syndrome, heart failure, and septic shock (Zhou et al., 2020). Severe infection may include multi-organ failure, reduced lung capacity, which is due to uncontrolled acute inflammation. SARS-CoV-2 can damage tissue at the alveolar level, characterized by pathological changes of tissue, infiltration, and hyperplasia. Other features of COVID-19 infection are high inflammatory response levels, lung cells infiltration of immune cells, thrombosis, and multi-organ failure (Zabetakis et al., 2020).In addition to these, other chronic diseases such as diabetes may increase the inflammatory response elicited by COVID-19 and increase the risk of mortality (Gupta et al., 2020). The excessive body mass index and adiposity are considered risk factors 
for complications arising from COVID-19 infection (Wu, 2020).

Similarly, blood vessels damaged in hypertensive and diabetic patients have an increased risk of suffering COVID-19 derived thrombotic complications. Due to the novelty of this disease, the scientific community is currently trying to prepare effective vaccines to treat pathology. One of the biggest challenges is the reduction of inflammation without compromising the patient's immune response. In the present scenario, the scientific community should focus not only on effective medicine but also on nutrition. The present review was aimed to highlight the link between nutrition, immune system, and COVID-19 for proper direction and clinical advice in medical research. Thus, the effects of bio-molecules and nutritional foods on the immune system and COVID -19 patients and dietetic recommendations for patients of COVID-19 etc., are discussed.

\section{Dietetic Nutrients on Immune Function and COVID-19}

The influence of nutrition on the immune system has been extensively studied. Many studies have also explored the impact of ample nutritional status and the recommended intake of a specific diet to boost immunity. However, due to the novelty of the disease, proofs related to the effects of nutrients on COVID-19 patients are rare. Protein deficiency leads to impairment of immune system function due to its negative effects on the amount of functional immunoglobulin and gutassociated lymphoid tissue. Both the quantity and the quality of proteins play an important role in boosting the immune system. It has been reported that high biological value proteins (eggs, lean meat, fish, and dairy products) have essential amino acids, which exert an anti-inflammatory effect. Some amino acids, such as arginine and glutamine, can modulate the immune system (Iddir et al., 2020). The eicosapentaenoic acid (EPA), omega-3 fatty acids, and docosahexaenoic acid (DHA) can inactivate viruses by modifying the host lipid conditions for viral replication. On the other hand, prostaglandin (pro-inflammatory) suppresses by the production of EPA and DHA, which inhibit cyclooxygenase enzymes (COX) (Zabetakis et al., 2020).

Additionally, they are converted enzymatically to proresolving mediators, such as protectins, resolvins (Duvall and Levy, 2016). The above-mentioned effects of DHA and the EPA were significant in reducing the severity and improving patients' recovery with COVID19. On the other hand, polar lipids (glycolipids, phospholipids or sphingolipids) can mask the plateletactivating factor and its receptor; and exert antiinflammatory effects ; and are beneficial in curing the COVID-19. It has also been reported that these lipids species regulate the enzymatic activity involved in PAF biosynthesis (Lordan et al., 2020).

Dietary fibres and carbohydrates have also been reported to have effects on immune system function. Consumption of higher glycemic index food such as highly processed carbohydrates may cause mitochondrial overload and synthesis of free radicals. It increases the blood levels of inflammatory cytokines such as $\mathrm{C}$ reactive protein, tumour necrosis factor-alpha, and interleukin-6(Monnier et al.,2006). The fibres have importance in metabolic functioning and an adequate intake may reduce systemic and gut inflammation. The consumption of fibrous foods has been related to lower inflammatory cytokines and enhanced levels of shortchain fatty acids(Iddir et al., 2020). Substances such as acetate, propionate, and butyrate have direct antiinflammatory effects, which inhibit the release of proinflammatory molecules and decreasing the expression of nuclear factor $\mathrm{kB}$. These substances also play an important role in maintaining adequate gut microbiota by increasing diversity, enhancing the presence of specific health-associated bacteria(Carlson et al., 2018). Besides gut microbiota, nasopharyngeal microbiota also plays an important role in respiratory infections. Therefore it has been reported that this kind of infections may result in altered gut microbiota and innate immune system response(Marsland et al., 2015). Because COVID-19 has been related to respiratory and gastrointestinal symptoms, it seems plausible that gut microbiota can enhance the inflammatory status.

\section{Vitamins and other nutrients}

Vitamins and minerals are good constituents of the diet and play an important role in maintaining immunity (Table 1). Different vitamins such as A, B, C, D, E, iron, magnesium and trace elements including zinc, selenium and copper (Maggini et al., 2008, Maggini et al., 2018) play an important role in disease susceptibility and immune function maintenance(Calder, 2013). Deficiencies of these nutrients affect the immune system and decrease the resistance against infections. The vitamins and minerals are important for immunity maintaining, differentiation and proliferation of lymphocyte, production of cytokine and antibody, and generation of memory cells.

\section{Vitamin A}

This vitamin is fat-soluble and named anti-infective and many of the body's defences against infection depend on adequate supply. Deficiency may result in impaired immune response, measles and diarrhoea. The supplementation of this vitamin reduces morbidity and mortality in infectious diseases such as diarrheal disease, HIV infection, malaria and measles-related pneumonia. Vitamin A plays an essential role in curing respiratory infections due to its involvement in forming the healthy mucus layer and enhancing antigen non-specific im- 
mune response (McCullough et al., 1999). Certainly, the histopathological changes have been described in pulmonary epithelium and parenchyma in a patient with vitamin A deficiency, which impair respiratory function (Timoneda et al., 2018).

\section{Vitamins B}

This water-soluble vitamin acts as part of coenzymes required for protein metabolism and hundreds of body and immune function reactions. Low intake of this vitamin weakens the immune system and response. Therefore it is recommended to include this vitamin in the diet of virus-infected patients to enhance their immune system(Mikkelsen and Apostolopoulos, 2019, Hira Shakoor et al., (2021).

\section{Vitamin C}

This vitamin is called ascorbic acid and act as antioxidant and plays a key role in collagen synthesis. Many research studies carried out and consider high doses of vitamin $\mathrm{C}$ to be so powerful antiviral. It may be considered a functional immunization for a variety of influenza strains. It acts as an anti-histamine agent and provides relief from flu-like symptoms such as sneezing, runny and swollen sinuses. It prevents susceptibility to lower respiratory tract infections. Significant research studies revealed the usage of vitamin C as a remedy for colds (Zabetakis et al., 2020). There is no evidence so far to recommend its supplementation for COVID-19. In this respect, a clinical trial to analyse the effect of this vitamin was carried out in 140 patients with severe COVID-19 in Wuhan (China) (Carr, 2020), who reported elevated inflammation in hypovitaminosis $\mathrm{C}$ and suggested that patients need nutritional therapy.

\section{Vitamin D}

It is known as the "sunshine" vitamin and acts as a nutrient and a hormone. It can be synthesized in the body with the help of sunlight.It plays an important role in bone integrity and stimulates the maturation of cells, including immune cells. The housebound peoples, institutionalized and night workers may have vitamin $D$ deficiency. Old age people also have a chance of vitamin D deficiency due to limited exposure to sunlight. The effects of vitamin $D$ deficiency on respiratory tract infections and lung injury have been widely reported(Xu et al., 2017). Furthermore, the studies have demonstrated that high-dose supplementation of vitamin D is safe and effective in improving the health status of mechanically ventilated critically ill patients by enhancing the capacity of blood for oxygen transport and increasing haemoglobin levels (Han et al., 2016, Smith et al., 2018). The studies revealed the role of vitamin $D$ in the prevention of COVID-19 and the mortality induced by this disease (llie et al., 2020).

\section{Vitamin E}

This vitamin is associated with the humoral and innate immune and it scavenges reactive oxygen species (ROS), reduces oxidative stress, and exerts antiinflammatory effects. Vitamin $E$ also protects immune cells from oxidation and polyunsaturated fatty acids. To date, there is little evidence regarding the use of vita$\min E$ as a therapeutic agent against COVID-19 (Moriguchi and Muraga,2000)

\section{Zinc}

This dietary trace mineral is important for the development and maintenance of the innate as well as the adaptive immune system. Deficiency of this mineral leads to dysfunction of both cell-mediated and humoral immunity and increases susceptibility to pathogens. It also reduces measles-related morbidity and mortality caused by lower respiratory tract infections in zincdeficient children. Increasing intracellular zinc concentration can efficiently impair the replication of a variety of RNA viruses. Studies revealed that increased concentration of $\mathrm{Zn}^{2+}$ inhibits the replication of SARScoronavirus(TeVelthuis et al., 2010), while its deficiency leads to defective cell-mediated immune response and increase the susceptibility for various infections. It has been suggested that increased intake of zinc can reduce gastrointestinal and respiratory symptoms and exert beneficial effects on RNA virus, including COVID19 infections(McCarty and DiNicolantonio, 2020).

\section{Copper}

There are many reviews on the role of copper in immunity and host susceptibility to infection. With antimicrobial property, copper can support the activity of macrophages, monocytes, neutrophil and natural killer cells. It can promote the proliferation of $\mathrm{T}$ lymphocyte and the production of IL-2. The deficiency of copper in animals weakens their immune system and increases their vulnerability to pathogens. The study carried out in rodent animals and reported that copper intake might reduce inflammation(Liu et al.,2016).

\section{Selenium}

Interestingly, the highest and lowest trace elements present in food depend upon the soils' geographical differences. Research studies reported that infected patients from areas with high selenium levels were more prone to recover from COVID-19(Zhang et al., 2020). Selenium plays an important role in antiinflammatory actions and has an essential role in the immune system. A positive association has been identified between the higher recovery rate from COVID-19 infection and adequate selenium status in 17 cities outside the region of Hubei (China)(Zhang et al., 2020). The selenium plays a significant role against viral infections, including HIV (Baum et al.,1997; Taylor et al., 
Table 1. Role of micronutrients to boost the immune system (Source: White Paper 2020).

\begin{tabular}{|c|c|c|c|c|}
\hline Micronutrient & Nutritional benefit & Innate immune function & $\begin{array}{l}\text { Adaptive immune } \\
\text { function }\end{array}$ & $\begin{array}{l}\text { Scientific } \\
\text { evidence }\end{array}$ \\
\hline Vitamin C & $\begin{array}{l}\text { - Helps to reduce the du- } \\
\text { ration and severity of the } \\
\text { common cold } \\
\text { - Works with vitamin E to } \\
\text { protect omega-3 PUFAs } \\
\text { and their structures }\end{array}$ & $\begin{array}{l}\text { - Boosts plasma neutrophil con- } \\
\text { centration } \\
\text { - Promotes neutrophil function } \\
\text { and mobility to accelerate im- } \\
\text { mune cell response } \\
\text { - Helps to reduce presence of } \\
\text { radicals and oxidants and pro- } \\
\text { tects against oxidative stress } \\
\text { - Promotes phagocyte activity }\end{array}$ & $\begin{array}{l}\text { - Promotes the mat- } \\
\text { uration of T lym- } \\
\text { phocytes } \\
\text { - Accelerates the } \\
\text { decomposition of } \\
\text { histamine }\end{array}$ & $\begin{array}{l}\text { Strong scien- } \\
\text { tific evidence } \\
\text { substantiated } \\
\text { by EFSA } \\
\text { health claims }\end{array}$ \\
\hline Vitamin D3 & $\begin{array}{l}\text { - Supports overall health } \\
\text { and wellbeing and bone } \\
\text { health } \\
\text { - Facilitates normal im- } \\
\text { mune function } \\
\text { - May reduce risk of auto- } \\
\text { immune disorders }\end{array}$ & $\begin{array}{l}\text { - Helps to reduce susceptibility } \\
\text { to pathogens }\end{array}$ & $\begin{array}{l}\text { - May suppress } \\
\text { excessive adap- } \\
\text { tive immunity re- } \\
\text { sponses }\end{array}$ & \\
\hline Vitamin B6 & $\begin{array}{l}\text { - Supports healthy func- } \\
\text { tioning of the nervous } \\
\text { system and red blood } \\
\text { cell formation } \\
\text { - Facilitates normal im- } \\
\text { mune function }\end{array}$ & $\begin{array}{l}\text { - Supports overall immune sys- } \\
\text { tem function } \\
\text { - Contributes to production of } \\
\text { DNA and proteins in the im- } \\
\text { mune system } \\
\text { - Boosts NKC activity }\end{array}$ & $\begin{array}{l}\text { - Supports antibody } \\
\text { production and } \\
\text { metabolism } \\
\text { - Boosts lymphocyte } \\
\text { proliferation }\end{array}$ & \\
\hline Vitamin A & $\begin{array}{l}\text { - Supports normal function } \\
\text { and development of both } \\
\text { the innate and adaptive } \\
\text { immune systems } \\
\text { - Mediates functions re- } \\
\text { quired for growth and } \\
\text { development }\end{array}$ & $\begin{array}{l}\text { - Enhances the body's ability to } \\
\text { shield itself against the threat } \\
\text { of pathogens } \\
\text { - Modulates innate immune re- } \\
\text { sponses }\end{array}$ & $\begin{array}{l}\text { - Contributes to the } \\
\text { proliferation and } \\
\text { differentiation of } \\
\text { antibody produc- } \\
\text { ing lymphocytes } \\
\text { - Modulates T cell } \\
\text { response }\end{array}$ & \\
\hline Selenium & $\begin{array}{l}\text { - Required for optimal } \\
\text { immune function } \\
\text { - Helps to reduce risk of } \\
\text { susceptibility to bacterial } \\
\text { or viral infections }\end{array}$ & $\begin{array}{l}\text { - Acts as an antioxidant to pro- } \\
\text { tect against oxidative damage, } \\
\text { through the reduction in reac- } \\
\text { tive oxygen species } \\
\text { - Regulates inflammatory pro- } \\
\text { cesses }\end{array}$ & $\begin{array}{l}\text { - Regulates immune } \\
\text { responses }\end{array}$ & \\
\hline Zinc & $\begin{array}{l}\text { - Protects against the ef- } \\
\text { fects of reactive oxygen } \\
\text { compounds } \\
\text { - Supports optimal im- } \\
\text { mune function, particu- } \\
\text { larly in athletes }\end{array}$ & $\begin{array}{l}\text { - Promotes growth, maturation } \\
\text { and activity of innate cells, like } \\
\text { NKCs }\end{array}$ & $\begin{array}{l}\text { - Promotes growth, } \\
\text { maturation and } \\
\text { activity of adaptive } \\
\text { cells, like B and T } \\
\text { lymphocytes }\end{array}$ & \\
\hline Vitamin E & $\begin{array}{l}\text { - Works with vitamin C to } \\
\text { protect omega-3 PUFAs } \\
\text { and their structures } \\
\text { - Supports overall im- } \\
\text { proved immune health } \\
\text { and function } \\
\text { - Improves wound healing }\end{array}$ & $\begin{array}{l}\text { - Protects omega-3 PUFAs } \\
\text { against attack from reactive } \\
\text { molecules } \\
\text { - Supports defense against oxi- } \\
\text { dative damage } \\
\text { - Reduces inflammation }\end{array}$ & $\begin{array}{l}\text { - Increases re- } \\
\text { sistance against } \\
\text { pathogens }\end{array}$ & $\begin{array}{l}\text { Emerging } \\
\text { scientific } \\
\text { evidence }\end{array}$ \\
\hline $\begin{array}{l}\text { Omega-3 } \\
\text { LCPUFAs }\end{array}$ & $\begin{array}{l}\text { - Supports optimal im- } \\
\text { mune function } \\
\text { - Supports early life im- } \\
\text { mune system develop- } \\
\text { ment }\end{array}$ & $\begin{array}{l}\text { - Modulates eicosanoid produc- } \\
\text { tion }\end{array}$ & $\begin{array}{l}\text { - Modulates eico- } \\
\text { sanoid production }\end{array}$ & \\
\hline Polyphenols & $\begin{array}{l}\text { - Reduces the symptoms } \\
\text { of the common cold and } \\
\text { influenza }\end{array}$ & $\begin{array}{l}\text { - Acts as an antioxidant to pro- } \\
\text { tect against oxidative damage }\end{array}$ & $\begin{array}{l}\text { - Boosts the number } \\
\text { of T lymphocytes } \\
\text { involved in the } \\
\text { adaptive response }\end{array}$ & \\
\hline
\end{tabular}


2016), hepatitis B linked liver cancer (Steinbrenner et al., 2015) and epidemic haemorrhagic fever(Hou, 1997). The recovery rate of COVID-19 patients was almost threefold higher in Enshi in Hubei Province, which has the highest intake of selenium in China, compared to the other cities in Hubei. The selenium intake was lowest in Heilongjiang Province overall world, which led to an almost fivefold death rate from COVID-19 than the average of all the other provinces outside of Hubei. All the above observations advocated the relation between intake of selenium and clinical outcome in COVID-19 patients.

\section{Iron}

Iron is a nutrient associated with COVID-19, and it corrects the functioning of the immune system. It is also well established that iron-containing enzymes are essential for replicating the virus, particularly coronaviruses (Liu et al., 2020). Studies reported that treatments with iron chelator deferiprone increase patients' survival with HIV (Costagliol et al., 1994, Kaufmann and McMichael, 2005). Evidence also advocates the antiviral activity of iron chelators on HIV by elevating intracellular iron efflux and increasing iron exporter ferroportin expression (Green et al., 2001).

\section{Water}

Water is necessary during the months of drier winter to keep our mucous membranes soft and moist, which prevent tiny cracks that allow entry of bacteria and viruses. Proper hydration leads to the transportation of blood, which carry plenty of oxygen to all the cells of the body, all organs, which need oxygen for proper functioning (Barry et al., 2010; Mooventhan and Nivethitha, 2014).

\section{Conclusion}

The nutrients are important for maintaining immunity and providing appropriate amounts of protein, fat, carbohydrate, vitamins, and minerals for the surveillance mode of keeping us from getting sick. These compounds do not store in the body; therefore, maintaining a primed state requires daily consumption to maximize exposure and thus benefits. Plenty of water, minerals such as zinc, copper, selenium, iron, magnesium, foods rich in vitamins, and a good lifestyle etc., can promote health and overwhelm this coronavirus infection. Intake of healthy food is also good for people with chronic pain, people struggling with obesity, diabetes, cardiovascular disease, cognitive dysfunction like anxiety and depression. Priming immune cells promote a faster and stronger response and are supported by dietary compounds consistent with health benefits. Thus, healthy foods can reduce the risk of infection of COVID
-19 and may help in the prevention of the disease.

\section{Conflict of interest}

The author declares that she has no conflict of interest.

\section{REFERENCES}

1. Barry, M., Popkin, Kristen E. D'Anci, \& Irwin H. Rosenberg (2010). Water, Hydration and Health, Nutr Rev., 68(8), 439-458. doi: 10.1111/j.1753-4887.2010.00304.x.

2. Baum, M.K., Shor-Posner, G., Lai, S., Zhang, G., Lai H., Fletcher, M.A., Sauberlich, H. \& Page, J.B.(1997). High risk of HIV-related mortality is associated with selenium deficiency. J. Acquir. Immune Defic. Syndr. Hum. Retrovirol.,15,370-374. doi: 10.1097/00042560-19970815000007.

3. Calder, P.C.(2013). Omega-3 polyunsaturated fatty acids and inflammatory processes: Nutrition or pharmacology? Br.J. Clin.Pharmacol, 75, 645-662.doi: 10.1111/ j.1365-2125.2012.04374.x.

4. Carlson, J.L., Erickson, J.M., Lloyd, B.B. \&Slavin, J.L. (2018). Health effects and sources of prebiotic dietary fiber. Curr. Dev. Nutr.;2:nzy005. doi: 10.1093/cdn/nzy005.

5. Carr, A.C.(2020). A new clinical trial to test high-dose vitamin $C$ in patients with COVID-Crit. Care. ;7;24 (1):133. doi: 10.1186/s13054-020-02851-4.

6. Costagliola, D.G., de Montalembert, M., Lefrere, J.J., Briand, C., Rebulla, P., Baruchel, S., Dessi, C., Fondu, P., Karagiorga, M. \&Perrimond, H.(1994). Dose of desferrioxamine and evolution of HIV-1 infection in thalassaemic patients. Br. J. Haematol..87:849-852. doi: 10.1111/j.1365 -2141.1994.tb06750.x.

7. Duvall, M.G.\&Levy, B.D. (2016). DHA-and EPA-derived resolvins, protectins, and maresins in airway inflammation. Eur. J. Pharmacol.;785:144-155.doi: 10.1016/ j.ejphar.2015.11.001.

8. Green, D.A., Antholine, W.E., Wong, S.J., Richardson, D.R. \&Chitambar, C.R. (2001). Inhibition of malignant cell growth by 311 , a novel iron chelator of the pyridoxalisonicotinoylhydrazone class: Effect on the R2 subunit of ribonucleotidereductase. Clin. Cancer Res.,7:3574-3579.

9. Gupta, R., Hussain, A. \&Misra, A.(2020). Diabetes and COVID-19: Evidence, current status and unanswered research questions. Eur. J. Clin. Nutr. ;74:864-870.

10. Han, J.E., Jones, J.L., Tangpricha, V., Brown, M.A., Brown, L.A.S., Hao, L., Hebbar, G., Lee, M.J., Liu, S. \&Ziegler, T.R.(2016). High dose vitamin D administration in ventilated intensive care unit patients: A pilot double blind randomized controlled trial. J. Clin. Transl. Endocrinol.,4:59-65.oi: 10.1016/j.jcte.2016.04.004.

11. Hira Shakoor, Jack Feehan, Kathleen Mikkelsen, Ayesha S. Al Dhaheri, Habiba I. Ali, Carine Platat, Leila Cheikh Ismail, Lily Stojanovska \& Vasso Apostolopoulos (2021). Be well: A potential role for vitamin B in COVID-19. Maturitas. 144: 108-111.doi: 10.1016/j.maturitas.20 20.0 8.007.

12. Hou, J.C. (1997). Inhibitory effect of selenite and other antioxidants on complement-mediated tissue injury in patients with epidemic haemorrhagic fever. Biol. Trace Elem. Res.,56:125-130.doi: 10.1007/BF02778988. 
13. Iddir, M., Brito, A., Dingeo, G., Fernandez, Del Campo S.S., Samouda, H., La Frano, M.R. \& Bohn, T.(2020). Strengthening the immune system and reducing inflammation and oxidative stress through diet and nutrition: Considerations during the COVID-19 crisis. Nutrients;12:1562.doi: 10.3390/nu12061562.

14. Ilie, P.C., Stefanescu, S. \& Smith, L. (2020). The role of vitamin D in the prevention of coronavirus disease 2019 infection and mortality. Aging Clin. Exp. Res.,. 1-4, doi: 10.1007/s40520-020-01570-8.

15. International Society for Infectious Diseases (2020).ProMed «PRO/AH/EDR> COVID-19 update (59): Global, cruise ship, more countries, WHO. (accessed on August 9 2020); Int. Soc. Infect. Dis. Available online: https://promedmail.org.

16. Kaufmann, S.H. \& McMichael, A.J. (2005). Annulling a dangerous liaison: Vaccination strategies against AIDS and tuberculosis. Nat. Med., 11:S33-S44. doi: 10.1038/ $\mathrm{nm} 1221$.

17. Liu, L., Geng, X., McDermott, J., Shen J., Corbin, C. Xuan, S., Kim, J., Zuo, L. \&Liu, Z.(2016). Copper deficiency in the lungs of TNF-alpha transgenic mice. Front. Physiol.,7:234. https://doi.org/10.3389/fphys.2016.00234.

18. Liu, W., Zhang, S., Nekhai, S. \& Liu, S. (2020). Depriving iron supply to the virus represents a promising adjuvant therapeutic against viral survival. Curr.Clin.Microbiol. Rep., 7:13-19.doi: 10.1007/s40588-020-00140-w.

19. Lordan, R., Tsoupras, A. \&Zabetakis, I. (2020). Platelet activation and prothrombotic mediators at the nexus of inflammation and atherosclerosis: Potential role of antiplatelet agents. Blood Rev.,100694. DOI: 10.1016/ j.blre.2020.100694.

20. Maggini, S., Beveridge, S., Sorbara, P.J.P. \&Senatore, G (2008). Feeding the immune system: The role of micronutrients in restoring resistance to infections. CAB Rev.;3:121.DOI:10.1079/PAVSNNR20083098.

21. Maggini, S., Pierre, A. \&Calder, P.C. (2018). Immune function and micronutrient requirements change over the life course. Nutrients.;10:1531.doi: 10.3390/nu10101531.

22. Marsland, B.J., Trompette, A. \& Gollwitzer, E.S. (2015). The gut-lung axis in respiratory disease, Ann Am Thorac. Soc., 12, S150-S156.

23. McCarty, M.F. \&DiNicolantonio, J.J.(2020). Nutraceuticals have potential for boosting the type 1 interferon response to RNA viruses including influenza and coronavirus. Prog.Cardiovasc. Dis.,63:383-385. doi: 10.1016/ j.pcad.2020.02.007.

24. McCullough, F.S., Northrop-Clewes, C.A.\&Thurnham, D. I. (1999). The effect of vitamin A on epithelial integrity. Proc. Nutr. Soc.;58:289-293.doi: 10.1017/s002966519900 0403.

25. Mikkelsen, K. \&Apostolopoulos, V. (1999).Vitamin B.1, B2, B3, B5, and B6 and the immune system. Nutr. Immunity.115-125.

26. Monnier, L., Mas, E., Ginet, C., Michel, F., Villon, L., Cristol, J.P.\& Colette, C.(2006). Activation of oxidative stress by acute glucose fluctuations compared with sustained chronic hyperglycemia in patients with type 2 diabetes. J.A.M.A.;295:1681-1687.doi: $\quad$ 10.1001/jama.295.14.16 81.

27. Mooventhan, A. \& Nivethitha, L.(2014). Scientific evidence -based effects of hydrotherapy on various systems of the
body.,N. Am. J. Med. Sci.; 6(5): 199-209. doi: 10.410 3/1947-2714.132935.

28. Moriguchi, S. \& Muraga, M. (2000).Vitamin E and immunity. VitamHorm., 59:305-336.

29. Steinbrenner, H., Al-Quraishy, S., Dkhil, M.A., Wunderlich, F. \& Sies, H. (2015). Dietary selenium in adjuvant therapy of viral and bacterial infections. Adv. Nutr.,6:73-82. doi: 10.3945/an.114.007575.

30. Smith, E.M., Jones, J.L., Han, J.E., Alvarez, J.A., Sloan, J.H., Konrad, R.J., Zughaier, S.M., Martin, G.S., Ziegler, T.R. \& Tangpricha, V.(2018). High-Dose vitamin D3 administration is associated with increases in hemoglobin concentrations in mechanically ventilated critically ill adults: A pilot double-blind, randomized, placebocontrolled trial. JPEN J. Parenter. Enter. Nutr.,42:8794.doi: $10.1177 / 0148607116678197$.

31. Taylor, E.W., Ruzicka, J.A., Premadasa, L. \& Zhao, L. (2016). Cellular selenoprotein mRNA tethering via antisense Interactions with ebola and HIV-1 mRNAs may impact host selenium biochemistry. Curr.Top. Med. Chem.,16:1530-1535. doi: 10.2174/156802661566615 0915121633.

32. TeVelthuis, A.J., van den Worm, S.H., Sims, A.C., Baric, R.S., Snijder, E.J. \& van Hemert, M.J.(2010). Zn(2+) inhibits coronavirus and arterivirus RNA polymerase activity in vitro and zinc ionophores block the replication of these viruses in cell culture. Plos Path. 4, 6(11):e1001176. doi: 10.1371/journal.ppat.1001176.

33. Timoneda, J., Rodriguez-Fernandez, L., Zaragoza, R., Marin, M.P., Cabezuelo, M.T., Torres, L., Vina, J.R.\& Barber, T.(2018). Vitamin A deficiency and the lung. Nutrients. 10:1132. doi: 10.3390/nu10091132.

34. White Paper (2020).Nutritional solutions to optimize your immunity. Nutritional solutions January, 2020, Dutch State Mines.

35. Wu, Z. (2020). Characteristics of and important lessons from the coronavirus disease 2019 (COVID-19) outbreak in China: Summary of a report of 72314 cases from the Chinese centre for disease control and prevention. J.A.M.A.;323:1239-1242. doi: 10.1001/jama.2 020.2 648.

36. Xu, J., Yang, J., Chen, J., Luo, Q., Zhang, Q. \& Zhang, H. (2017). Vitamin D alleviates lipopolysaccharide-induced acute lung injury via regulation of the renin angiotensin system. Mol. Med. Rep.,16:7432-7438. doi: 10.3892/ mmr.2017.7546.

37. Zabetakis, I., Lordan, R., Norton, C. \& Tsoupras, A.(2020). COVID-19: The inflammation link and the role of nutrition in potential mitigation. Nutrients. ;12:1466.doi: 10.3390/ nu12051466.

38. Zhang, J., Taylor, E.W., Bennett, K., Saad, R. \& Rayman, M.P.(2020).Association between regional selenium status and reported outcome of COVID-19 cases in China. Am. J. Clin. Nutr.,111:1297-1299. doi: 10.1093/ ajcn/nqaa095.

39. Zhou, F., Yu, T., Du R., Fan, G., Liu, Y., Liu, Z., Xiang, J., Wang, Y., Song, B. \& Gu, X.(2020). Clinical course and risk factors for mortality of adult inpatients with COVID-19 in Wuhan, China: A retrospective cohort study. Lancet, 395,1054-1062. doi: 10.1016/S0140-6736(20)30566-3. 